Katarína Koštialová

ORCID https://orcid.org/0000-0002-3573-9353

Katedra sociálnych štúdií a etnológie

Filozofická fakulta, Univerzita Mateja Bela v Banskej Bystrici

Slovensko

Roman Hofreiter

ORCID: https://orcid.org/0000-0003-2422-8301

Katedra sociálnych štúdií a etnológie

Filozofická fakulta, Univerzita Mateja Bela v Banskej Bystrici

Slovensko

\title{
Fenomén návratu domov. Mladí liudia a ich návrat zo zahraničia na Slovensko
}

\section{The phenomenon of return. Young people and their return to Slovakia from abroad}

\begin{abstract}
Migration and migration experience currently present an important phenomenon for a variety of social groups of general public in Slovakia. Migration is considered to be one of key civilization challenges. The main aim of the paper is to provide the first findings about a relatively overlooked topic of the young people's return home from abroad. The paper deals with the young migrants's decision-making process with regards to their return home. Its complementary part is the cultural shock upon their re-entry. We observe the role of the category of "home" in the process of returning and the dimensions that are associated with it. In addition, we are interested in what creates the feeling of being "home again" in its positive and negative connotations. We analyse the four overlapping and interactive dimensions of home: the spatial, temporal, emotional and rational ones, which we support with the results of field research. The research was made on the basis of interviews with young people in Slovakia.
\end{abstract}

Key Words : young people, migration, home, return, Slovakia 
Migrácia a migračná skúsenost’ v súčasnosti predstavuje významný fenomén pre rôzne skupiny obyvatel’stva na Slovensku. Je považovaná za jednu z klúčových civilizačných výziev. Hlavným zámerom tejto štúdie je priniest' prvé poznatky o pomerne málo riešenej problematike, ktorou je dôvod pre návrat mladých ludí domov. Príspevok sa zaoberá procesom rozhodovania mladých migrantov pre návrat domov, pričom jeho komplementárnou súčastou je aj kultúrny šok z návratu. Všímame si, akú úlohu v tomto procese zohráva kategória domova a aké dimenzie sa s ním spájajú. Čo kreuje pocit „opät doma“v pozitívnych i negatívnych konotáciách. Bližšie sa venujeme štyrom prekrývajúcim sa a interaktívnym rozmerom domova: priestorovému, časovému, emocionálnemu a racionálnemu, ktoré podopierame výsledkami terénneho výskumu. Výskum bol realizovaný na základe rozhovorov s mladými l’ud’mi na Slovensku.

Kl'účové slová: mladí ludia, migrácia, domov, návrat, Slovensko

Odebrano / Received: 31.01.2019

Zaakceptowano / Accepted: 27.08.2019

\section{Úvod}

V štúdii sa venujeme jednej z tematických úloh, ktorú riešime na našom pracovisku v rámci projektu Horizont 2020: Podpora zapojenia a sociálnej angažovanosti mládeže: Príležitosti a výzvy mladých ludi „v konflikte"v Európe. Ide o výskum mladých l’udí, ktorí žili, študovali alebo pracovali v zahraničí a rozhodli sa vrátit spät domov, na Slovensko. $\mathrm{V}$ štúdii chceme priblížit proces rozhodovania mladých migrantov pre návrat, pričom jeho komplementárnou súčastou je aj kultúrny šok z návratu. Všímame si, akú úlohu $\mathrm{v}$ tomto procese zohráva kategória domova a aké dimenzie sa s ním spájajú. Čo kreuje pocit „opät doma“ v pozitívnych i negatívnych konotáciách. Bližšie sa venujeme štyrom prekrývajúcim sa a interaktívnym rozmerom domova: priestorovému, časovému, emocionálnemu a racionálnemu ${ }^{1}$, ktoré podopierame výsledkami terénnych výskumov. $V$ texte využívame viaceré výpovede respondentov, ktoré považujeme za nenahraditel'né sentencie k danej téme.

Migrácia predstavuje významný medzník v živote (nielen) mladého človeka. Aj z tohto dôvodu analýzu migračných procesov nemožno obmedzit iba na redukcionistické chápanie odchodu. Fenomén migrácie môžeme rozčlenit z hl'adiska procesuálnej povahy do nasledujúcich fáz. Prvou je rozhodnutie sa pre odchod, (prečo/ proces rozhodovania, motivácia, vízie, ciele). Druhou fázou je samotná migrácia, prispôsobovanie sa novým skutočnostiam v krajine príchodu, kde jednotlivec musí zvládat adaptáciu na nové situácie, môže zažit kultúrny šok. Musí si budovat sociálne kontakty, osvojit si iný každodenný život a riešit nové situácie. Ďalšou fázou migračného cyklu, na ktorú sa v štúdii zameriame, je návrat domov. Tu sa opätovne stretávame s témou adaptácie, s možnost̉ou kultúrneho šoku a stretu vízií, idealizácie s realitou. Tak ako k odchodu, aj

1 Použili sme prístup Erdal 2014. 
pre návrat domov sa jednotlivec nerozhoduje spontánne bez bilancie svojej životne dráhy. Ide o zložitý, časovo náročný proces rozhodovania sa, hodnotenia aktuálnej situácie a zároveň projektovania svojej budúcnosti². V kontexte tejto štúdie ide o migráciu dobrovolnú a dlhodobú. Podmienkou dlhodobej migrácie je pohyb l’udí, ktorí zmenia krajinu svojho obvyklého pobytu na dobu aspoň jeden rok $^{3}$. Zároveň ide o dočasný typ migrácie, s konkrétnou motiváciou a/ alebo účelom, s úmyslom vrátit’ sa neskôr do krajiny pôvodu.

Migrácia a migračná skúsenost’ v súčasnosti predstavuje významný fenomén pre rôzne skupiny obyvatel'stva na Slovensku. Je považovaná za súčaste éry globalizácie, za jednu z klúčových civilizačných výziev vd’aka populačným, ekonomickým, kultúrnym, sociálnym, politickým, environmentálnym, bezpečnostným a iným dopadom ${ }^{4}$. Slovensko bolo súčastou viacerých migračných vín, ktoré zasiahli Európu ${ }^{5}$, ale jej súčasné formy migrácie za prácou, štúdiom či lepším životom majú iný charakter, pretože sa vnímajú ako jedno zo základných občianskych práv. Otázka hraníc a ich významu pre medzinárodnú mobilitu sa nezmenila po roku 1989, ale zmenili sa podmienky, ktoré mobilitu regulujú. Tie súvisia najmä so vstupom Slovenska do EU v roku 2004. Migráciu ul’ahčuje odstraňovanie administratívnych bariér, zvyšujúca sa politická a ekonomická integrácia, rozširovanie prístupu na pracovný trh, možností pre štúdium, rozvoj dopravnej infraštruktúry a informačných technológií, spoločenských a demografických zmien, zjednocovanie rodín i budovanie sociálnych sietít.

Štúdium migrácie a fenoménov s ňou spojených sa vyvinulo v samostatný interdisciplinárny výskumný a študijný odbor „migračné štúdiä“ (migration studies). Ich súčastou je aj pododbor ,antropológia/ etnografia návratu“ (anthropology/ethnography of return), ktorá sa zaoberá návratovou migráciou ${ }^{7}$. Kým v migráciách 19. a 20. storočia boli dôvody pre návrat možné vysvetlit z hladiska rodinných záväzkov (napríklad dedičských nárokov na otcovizeň), alebo ako dôsledok povojnových politických dohovorov o výmene obyvatel'stva alebo o repatriácii ${ }^{8}$, v súčasnosti sa nachádzame v odlišnej situácii ${ }^{9}$. Aktuálne zahraničné výskumy sa venujú predovšetkým ekonomickým súvislostiam tohto procesu. Skúmajú sa dôvody návratu do krajiny pôvodu, sleduje sa správanie reemigrantov na trhu práce, základné charakteristiky reemigrantov, kategória domova i obrátený kultúrny šok ${ }^{10}$. Výskumy taktiež ukazujú, že namiesto konceptu Brain drain, ktorý predpokladá nenávratný únik mozgov, nové štáty EU zažívajú skôr the brain

\footnotetext{
2 Majerová 2016.

${ }^{3}$ Medzinárodná organizácia pre migráciu (IOM), 08.11.2018.

${ }^{4}$ Divinský 2009.

${ }^{5}$ Historické kontexty migrácie nie sú predmetom tejto štúdie, a preto sa im nebudeme venovat.

${ }^{6}$ Divinský 2009.

7 Bitušíková 2006, s. 116.

${ }^{8}$ Paríková 2001.

${ }^{9}$ Botíková 2014, s. 192.

${ }^{10}$ Cassarino 2004; Erdal 2014; J Carling, Erdal 2014; Grabowska, Garapich 2016; Gray, Savicki 2015.
} 
circulation ${ }^{11}$. Znamená to, že migranti sa po určitom čase vracajú spät do krajiny pôvodu, prinášajú do nej nové skúsenosti a modifikujú život v nej.

Oproti početným publikačným výstupom zahraničnej proveniencie $\mathrm{v}$ období 2004-2008 sa na otázky migrácie v Slovenskej republike dlhodobo a komplexne špecializovalo len minimum vedeckých pracovníkov. Tento fakt mal za následok jeden z najnižších počtov fundovaných odborných výstupov v kontexte európskej únie ${ }^{12}$. Rastúca spoločenská závažnost' migrácie sa stala jednou z dôležitých tém v etnologickej a sociálno-antropologickej literatúre len $\mathrm{v}$ poslednom období ${ }^{13}$. K téme návratu, ktorá je lajtmotívom štúdie je absencia výskumov ešte výraznejšia. SR nemá spol’ahlivé kvantitatívne ani kvalitatívne zistenia o návrate mladých ludí domov na Slovensko. Oficiálne pracuje v zahraničí 150 tisíc Slovákov, čo predstavuje 7,50 \% zo všetkých ekonomicky aktívnych obyvatel'ov a väčšina $z$ nich, $70 \%$, je vo veku do 40 rokov $^{14}$. Okrem pracovnej migrácie je špecifickým znakom Slovenska vysoká migrácia vysokoškolských študentov zo Slovenska, pričom nemáme na mysli krátkodobé študijné mobility, ale full time. Podla výskumu na zahraničných vysokých školách študuje $15 \%$ všetkých študentov ${ }^{15}$ a $42 \%$ študentov sa po absolvovaní školy do dvoch rokov vracia domov.

\section{Metódy výskumu}

Pre zodpovedanie výskumných otázok v rámci riešenia danej témy sme sa zamerali na účelový typ vzorky (purposive sampling). Výber respondentov bol uskutočnený prostredníctvom osobných kontaktov, metódou snehovej gule (nabal'ovania d’alších respondentov) i za pomoci viacerých inštitúcií (Sokratov inštitút, Leaf). Pri výskume sme vychádzali z metodiky, ktorá bola určená v projekte, kde sú za mladých l’udí považovaní tí, ktorí spĺnajú kritérium 16-30 rokov. Náš výskum bol zameraný na tých, ktorí majú skúsenosti s dlhodobým pobytom (trval minimálne rok) v zahraničí a v súčasnosti žijú doma na Slovensku.

Vychádzame zo zistení $\mathrm{z}$ individuálnych híbkových rozhovorov, $\mathrm{v}$ rámci ktorých sme sa zamerali na osobné migračné príbehy. Realizovali sme 27 pološtrukturovaných rozhovorov. Priemerný vek respondentov v čase realizácie výskumu bol 27 rokov. Naši respondenti mali stredoškolské a vysokoškolské vzdelanie a pochádzali z rôznych oblastí Slovenska. Dôvod vycestovania: štúdium a vzdelávanie, práca, cestovanie, poznávanie a dobrodružstvo, ne/riešenie osobných problémov (rodinné, partnerské, pracovné).

\footnotetext{
${ }^{11}$ Martin, Radu 2012.

12 Divinský 2009.

${ }^{13}$ Problematike migrácie sa venuje napríklad: Bahna 2008, 2011, 2015; Bahna, Sekulová 2019; Botíková 2014; Búriková 2006, 2007; Búriková, Miller 2010; Divinský 2009; Divinský, Popjaková 2007; Divinský, Zachar-Podolinská 2018; Hlinčíková, Sekulová 2012; Jenčová 2007a, 2007b, 2008; Majerová 2016; Luther 2006a; Sekulová 2015.

${ }^{14}$ Reálne počty Slovákov pracujúcich v cudzine sú vyššie.

15 Bahna 2015, s. 1.
} 
Krajiny migrácie: Belgicko, Cyprus, Dánsko, Velká Británia, Indonézia, Malorka, Nemecko, Nórsko, Portugalsko, Rakúsko, Španielsko, Taliansko, Uruguaj, USA. Z výskumu sme vylúčili Českú republiku ako krajinu kultúrne podobnú a navyše, z Čiech prichádzajú študenti a zamestnaní domov aj niekolkkokrát za mesiac. Rozhovory boli nahrávané a prepísané, pričom bola vykonaná anonymizácia (respondentov, mien, krajín) tak, ako ju určila metodická príručka projektu. Rozhovory boli následne kódované (NVivo program - nástroj na kategorizáciu, klasifikáciu a analýzu najmä kvalitatívnych dát). Okrem rozhovorov sme realizovali obsahovú analýzu diskurzu o návrate v médiách i etnografické pozorovania. Dodržujúc anonymizáciu aj v štúdii, v zátvorkách za výpoved’ami uvádzame len pohlavie respondenta (m.)/ respondentky (̌̌.).

\section{Domov}

Ako sme uviedli, respondenti sa po určitom rozhodovacom procese vrátili domov na Slovensko, kde v súčasnosti žijú.

V slovenskej etnologickej spisbe sa problematika konceptualizácie domova vyskytuje zriedkavo, najmä v kontexte migrácií ${ }^{16}$. Jednou $\mathrm{z}$ posledne publikovaných je štúdia Daniela Luthera Koncepty domova a vztahy slovenských migrantov a emigrantov $k$ domovine, v ktorej sa opiera najmä o Bausingerov a Fox koncept domova. Konštatuje, že klúčové pojmy vztahujúce sa $\mathrm{k}$ obrazu domoviny sú pre emigrantov rodina, príbuzenstvo, priatel'ská skupina, rodisko, rodný jazyk, krajinný ráz, mentalita, ekonomické a sociálne postavenie, každodenný život ${ }^{17}$. Už z uvedeného vyplýva, že domov je zložitá, viacúrovňová a mnohostranná dimenzia, ktorá obsahuje sociálne, psychologické, kultúrne, politicko-ekonomické i finančné aspekty.

Prístupy, ktoré sa používajú na konceptualizáciu domova, sú rozmanitéé ${ }^{18}$. Domov je abstraktným symbolom s celou radou konotácií. Môže íst’ o hmotné a duchovné hodnoty, rodinu, priatel'ov, sociálny priestor domova, miesto socializácie, komunikácie, sebaidentifikácie, životný priestor z hladiska architektúry a vzṫahu k prostrediu. Zároveň je domov predstavovaný ako miesto pôvodu našej jedinečnosti a súnaležitosti a je tiež koncipovaný ako miesto formovania solidarity a pomoci ${ }^{19}$. Domov je aj lokálna kategória vo vztahu ku globálnemu ${ }^{20}$ a obsahuje aj význam práv a povinností.

Širšie chápanie domova zahŕňa geografickú lokalizáciu, krajinu, rodnú obec mesto, kde sa človek narodil, kam sa rád aj po rokoch vracia, alebo obec - mesto, v ktorom žije. Najširší význam má chápanie domova ako rodnej vlasti, ktoré si človek snád' najviac uvedomí, ked' vlast' z rôznych dôvodov dobrovolne či nedobrovol'ne opustil. Sociológ Fedor Gál v úvahe o vlasti a domove píše:

\footnotetext{
${ }^{16}$ Pozri napr. Paríková 2001; Bitušíková 2006; Jenčová 2007b; Hlinčíková, Sekulová 2012; Majerová 2016.

${ }^{17}$ Luther 2006b, s. 112.

${ }^{18}$ Viac Mallett 2004.

${ }^{19}$ Szaló 2006.

${ }^{20}$ Bitušíková 1999.
} 
Cítim to tak, že vlaste je ten priestor, v ktorom som sa stával človekom - jeho jazyk, kultúra, zvyky, tradície, jeho inštitúcie, politické zriadenie, jeho príroda, ludia, ktorí v ňom žijú. A čas, v ktorom sa to všetko udialo... Doma som tam, kde spávam, kde mám svoju knižnicu a pracovný stôl, kam utekám pred nepohodou [...] a kde - ako dúfam - raz zomriem. Domov si utváram sám, vlast' nie. Domov som schopný milovat', vlast' som schopný rešpektovat', ctit jej zákony a byt jej verný, ak ma nesklame ${ }^{21}$.

V užšom chápaní je domov predovšetkým intímny priestor, miesto komfortu a pohodlia, kde človek dennodenne žije, kde sa cíti dobre a bezpečne. Domov vytvárajú predmety, spomienky i zmyslové vnímanie: chut' (kulinárna kultúra - nápoje, jedlá), čuch (vôňa stromov, kvetov, mora), zvuk (preplneného mesta, vody, hudba). Pri tomto rozmanitom prístupe $\mathrm{k}$ chápaniu domova a jeho vytváraniu sa viacerí autori zhodujú v tom, že pri jeho konštruovaní ide predovšetkým o zdiel'anie osobnej skúsenosti a priestoru s d’alšími l’ud'mi, väčšinou členmi rodiny ${ }^{22}$.

Na ṫažkosti pri vymedzení pojmu domov poukazuje anglická právnička Lorna Fox, ktorá sa venuje právnemu konceptu domova. Vo svojej štúdií Význam domova: Chimérický koncept alebo právna výzva upriamuje pozornost' na Rapoportov vzorec ${ }^{23}$, podla ktorého „home $=$ house $+\mathrm{x}($ domov $=$ dom/obydlie $+\mathrm{x})$ “. Uvedený vzorec vyjadruje, že pojem domov tvorí z jednej strany fyzická štruktúra bydliska a na druhej strane aj premenlivý faktor x. Podl'a Fox vymedzenie fyzickej štruktúry domu neposkytuje koncepčné tažkosti, pretože to je betón, hmotný subjekt. Konceptuálnou výzvou vo vztahu k domovu je odhalit záhadný „x faktor“, ktorý predstavuje sociálne, psychologické a kultúrne hodnoty. A tie sú vo svojej podstate subjektívne. Domov teda nie je len fyzická budova, ale miesto s osobitným významom obsahujúcim vztahy, väzby, pocity. Tento vztah nie je viditel'ný a ani meratel'ný2 24.

Vnímanie domova je individuálne. $V$ súvislosti so súčasnými migračnými trendami sú vzt̉ahy k domovu ešte zložitejšie, jedinec môže mat domovov viacej. Domovom pre neho môže byt' krajina pôvodu i krajina migrácie. Viacerí autori poukazujú na to, že domov má tekutú povahu. Časom sa môže menit a jeho vnímanie je ovplyvnené priestorovými skutočnostami procesu migrácie. Domov môže byt’ „tu“, ale aj „tam“, prípadne oboje tu, aj tam ${ }^{25}$. Koncept „dvoch domovov je stabilizovaný aj v zmiešaných rodinách, najmä ak sa usídlili v rodnej krajine manželského partnera“"26.

\footnotetext{
${ }^{21}$ Bitušíková 1999, s. 8 (podla Gál 1998, s. 118-120).

${ }^{22}$ Galčanová, Vacková 2014, s. 14-15.

${ }^{23} \mathrm{Na}$ Rapoportov vzorec a koncept domova Lorny Fox upozorňuje vo svojej štúdii Luther 2006b.

${ }^{24}$ Fox 2002, s. 8.

${ }^{25}$ Erdal 2014; Vertovec 1999; Cassarino 2004; Szaló 2007.

${ }^{26}$ Luther 2006b, s. 112.
} 


\section{Návrat domov}

M. J. Westwood, W. S. Lawrence a D. Paul definujú návrat ako kontinuum skúseností a správania, ktoré sa vyskytujú vtedy, ked' sa jedinec vráti do miesta svojho pôvodu po tom, čo bol ponorený do iného kontextu na adekvátne dlhé obdobie. To je dôvodom na to, aby urobil určitý stupeň duševného a emocionálneho opätovného prispôsobenia sa pred optimálnym fungovaním $\mathrm{v}$,novom“ prostredí ${ }^{27}$. Táto definícia špecifikuje určitú úroveň akulturácie v hostitel'skej kultúre, ktorá si vyžaduje aj psychickú adaptáciu. Po návrate domov je potrebné opätovné prispôsobenie sa. Bez tejto empírie by návrat domov mohol byt prirovnaný k skúsenosti turistu, ktorý ide „len po povrchu kultúry“, čo nevyvoláva problémy s návratom. Ponorenie sa do inej kultúry, iného prostredia je to, čo prispieva k zložitosti návratu ${ }^{28}$.

I napriek tomu, že naša vzorka respondentov neodišla do zahraničia primárne s ciel'om trvalo sa usadit a na návrat domov sa tešili, proces rozhodovania sa preň bol náročný a dlhotrvajúci. Je to z toho dôvodu, že sa v krajine, mieste migrácie snažili integrovat', adaptovat', začlenit do sociálnych sietí, aktívne trávit’ svoj vol'ný čas, spoznávat' hostitel'skú krajinu, jej kultúru, športovat', vytvárat’ si nový domov a k nemu emotívnu väzbu. Počas pobytu v zahraničí viacerí z nich prešli inherentnou premenou. Získali nové zručnosti, skúsenosti, vedomosti, adaptovali sa na nové podmienky, boli konfrontovaní s ,inakostou“, s inými pomermi (sociálnymi, ekonomickými, kultúrnymi, rodovými), riešili dovtedy nepoznané situácie. Vplyvom nových skúseností došlo k ich prirodzenej sociálnej i kultúrnej premene, ale svoju zmenu si často uvedomili až po návrate domov. Zároveň sa prirodzene zmenil aj domov - ludia, prostredie, podmienky. $Z$ týchto dôvodov sa po návrate u niektorých respondentov prejavila dezilúzia. Viacerí autori tento stav dávajú do kontextu aj s idealizovaním svojho domova, ku ktorému po určitom období pobytu v zahraničí dochádza. Podl’a Katherine Brickell je domov jednou z najviac idealizovaných skúseností a scén ludskej existencie ${ }^{29}$. V časovej línii je domov spojený so spomienkami, spomínaním, tvorbou nostalgického viac-menej nemenného obrazu ${ }^{30}$. Preto sa stáva, že po návrate domov, pri konfrontácii nových skúseností a idealizácie domova s realitou dochádza ku kultúrnemu šoku z návratu (obrátený kultúrny šok), $\mathrm{v}$ angličtine reverse culture shock, reentry culture shock. Obrátený kultúrny šok predstavuje proces reštrukturalizácie, rekultivácie a reasimilácie do vlastnej kultúry potom, čo jednotlivec žil v inom priestore ${ }^{31}$. Pri návrate domov respondentom/ respondentkám vadilo najmä správanie Slovákov (pesimizmus, apatia, pasivita, korupcia), ktoré je podla nich v silách samotných l’udí zmenit.

\footnotetext{
${ }^{27}$ Gray, Savicky 2015, s. 264 (podla Westwood, Lawrence Paul 1986, s. 223).

${ }^{28}$ Gray, Savicky 2015, s. 264.

${ }^{29}$ Galčanová, Vacková 2014, s. 14 (podl’a Brickell 2012).

${ }^{30}$ Galčanová, Vacková 2014, s. 14.

${ }^{31}$ Gaw 2000, s. 85.
} 
Ja som bol nadšený, že už pôjdem po tých dvoch rokoch domov. Ale hned’ po príchode som tak nadšený nebol skoro z ničoho. Bol to strašný kultúrny šok. L’udia sa stažovali, ako klasicky sa ludia na Slovensku staažujú. Ja som si vtedy uvedomil, že bože, ved' ja som dva roky nepočul nikoho sa stažovat'. A teraz, ked' som sa vrátil tak som si to začal hned' uvedomovat', že sakra, že my sa naozaj tu stažujeme. Ale ani jeden nepohne prstom, že by sa zaangažoval a niečo urobil. Takže to bol najväčší šok, že proste tu ludia šomrú, že tu sú ovel’a agresívnejší ludia na cestách, že sa neusmievajú v obchodoch, že nie sú slušní, neprosia a nedakujú (m.).

Ked' sme sa vrátili, tak ja som si zvykala asi rok. Človek si ani neuvedomuje, že ako vel’mi je to tu iné ked' sa vráti [...]. To bolo ešte tažšie ako to, ked’ sme odišli. Adaptačné obdobie znovu si zvykat doma bolo velmi tažké. Teraz sú tri roky, čo sme spät a ten prvý rok bol naozaj taký náročný, že v podstate tie prvé mesiace som pomaly každý večer plakala, že som tu neštastná, že neviem čo d’alej (ž.).

Ako sme uviedli, proces rozhodovania pre návrat domov, ako aj samotný návrat nebol jednoduchý. Mladí reemigranti si museli formovat sociálne siete dvakrát. Nielen pri príchode do hostitel'skej krajiny, ale aj pri návrate domov. Väčší predpoklad pre udržanie pozitívnych kontaktov na dial'ku majú dlhodobé a intenzívne medziludské vztahy. Starat sa a rozvíjat ich je náročné na čas a závisí aj od hodnotových daností aktérov. Väčšina z nich udržiavala kontakt s krajinou pôvodu, či už komunikáciou s príbuznými, kamarátmi (skype, viber, facebook, whatsapp), alebo sledovaním novín, internetu a správ z domova. Udržiavanie interakcie cez sociálne médiá môže len čiastočne preklenút geografickú vzdialenost’ a diskontinuitu pravidelnejších stretnutí tvárou v tvár. Treba poznamenat', že nie vždy sa vztahy na dial'ku udržali a nie vždy sa pri návrate podarilo na ne nadviazat' v nezmenenej intenzite a kvalite. $V$ príbuzenskej rovine sa predstava o vzájomných väzbách v rodine a kvalite rodinného života pri návrate domov nielen naplnila, ale predčila očakávania. Rodinné väzby a komunikácia medzi jednotlivými členmi sa i zintenzívneli a zlepšili. Všetci respondenti zdôrazňovali, že najbližší členovia rodiny im preukazovali morálnu, psychickú, ekonomickú podporu a pomoc. Zároveň, rodičia akceptovali samostatnost', sociálnu dospelost’ svojho navrátivšieho sa „diet’ata“.

Väčším problémom boli kamarátske a priatel'ské väzby, na ktoré sa nepodarilo v plnej miere nadviazat. Na jednej strane to súvisí s dynamikou formovania životných a rodinných stratégií, ked' kamaráti zmenili miesto bydliska, prácu, prípadne si založili vlastné rodiny. $\mathrm{Na}$ strane druhej štruktúru vzt̉ahov narušili aj iné životné skúsenosti, ktoré mladí ludia nadobudli v zahraničí. ${ }^{32}$ Smer ich zmeny bol badatelný nielen v rovine analytickej, ale aj normatívnej a psychologickej. Na životný štýl spred migrácie nemohli a v niektorých prípadoch ani nechceli nadviazat'. Okrem pozitívnych ohlasov na ich návrat, najmä zo strany rodinných príslušníkov, sa respondenti stretli aj s nepochopením,

${ }^{32} \mathrm{~K}$ podobným zisteniam dospela na základe svojich výskumov aj Jenčová $2007 \mathrm{~b}$. 
nezáujmom i závistou. $V$ zahraničí boli migranti stigmatizovaní ich pôvodom, napríklad označením tá z východu a vo svojej krajine sa tiež stávajú „inými“, líšia sa. Stigma zostala aj v domácich podmienkach, len sa zmenila na migračnú skúsenost', napríklad označením tá, čo žila v Pariži. Nasledovné výpovede svedčia o tom, že návrat domov bol tažký a v niektorých prípadoch i traumatický. Adaptačné problémy súviseli najmä s pochybnostami co d'alej?, rozhodol/ a som sa správne? Pri zvládnutí tejto situácie boli odkázaní najmä sami na seba, pretože problémy, s ktorými sa reemigranti stretávali, boli schopní pochopit̉ najmä tí, ktorí boli podobne stigmatizovaní, teda mali migračnú skúsenost'. Aj preto viacerí z nich po návrate vyhl'adávali komunitu z cudziny navrátivších sa mladých l'udí.

Vrátila som sa na Slovensko, tak som sa tu musela naspät aklimatizovat'. Skôr tak vztahovo. Ked' som sa vrátila naspät', tak zrazu l'udia boli už inak poskupinkovaní. Musela som si zvyknút že títo sa už nekamarátia s tými, a títo s tými. Nevedela som kam si mám sadnút a s kým si mám sadnút, lebo každý už mal svojho partnera. Tak som si sadla sama. Priznám sa, že som sa aj tak cítila. Sama (̌̌.).

Ked’ som sa vrátila, bola som taká stratená a nevedela som čo robit', kde začat. Lebo ked’ som bola tri roky preč, tak aj tu sa ludia pomenili, išli preč, študovat', robit', prestahovali sa a nemala som už s nimi priamo kontakt. [...] Bolo to zlé, vel'mi vážne. Velmi vážne. Ja som nevedela čo d’alej, všetko sa mi zdalo zbytočné, že som sa trápila na tej tažkej škole, že som tam zvládla tie tažké chvíle aj to podceňovanie $z$ ich strany a tu som nevedela čo dalej, ako to zužitkovat'. Takže bolo to vel'mi vážne, až do depresie. Musela som vyhladat' odbornú pomoc u psychoterapeuta (ž.).

I napriek adaptačným taž̌kostiam pri návrate, mladí ludia hodnotili migračnú skúsenost' a návrat domov pozitívne. Tento vnútorný, subjektívny rozpor vychádza z empírie ktorá im umožnila vnímat’ ludí, vzt̉ahy, situáciu na Slovensku inak, vidiet Slovensko „novými očami““33, ocenit skutočnosti, ktorých si predtým neboli vedomí, či naopak vidiet kritickými očami rôzne nedostatky. Pre viacerých respondentov a respondentky sa po dlhšom pobyte zmenil koncept „domova“. Mladí l'udia formulovali skutočnost”, že si po pobyte v zahraničí začali jednoducho vážit Slovensko. Vážit si krajinu odkial' pochádzajú, kde žije ich rodina, kde sa cítia doma aj s nedokonalostami, resp. nevýhodami aj výhodami ${ }^{34}$.

\section{Dimenzie domova a návrat}

Ako sme upozornili, je vel'mi tažké uchopit široko poňatý koncept domova. V kontexte tejto štúdie sa opierame o koncept humánnej geografky Marty Bivand Erdal ${ }^{35}$,

\footnotetext{
${ }^{33} \mathrm{~K}$ podobným zistenia dospeli na základe svojich výskumov aj Hlinčíková, Sekulová 2012.

${ }^{34}$ Hlinčíková, Sekulová 2012, s. 11-12.

${ }^{35}$ Erdal 2014.
} 
ktorý uplatňujeme v d’alšom texte. Erdal analyzovala domov u navrátivších sa pol'ských a pakistanských migrantov a konceptualizovala ho prostredníctvom štyroch dimenzií: priestorovej, časovej, emocionálnej a racionálnej. Medzi týmito rozmermi existujú dôležité prepojenia, ktoré sú zároveň aj dostatočne odlišné, aby poskytli zaujímavé analytické údaje. Spomenuté dimenzie aplikujeme aj v procese návratu domov využijúc výpovede respondentov/ respondentiek.

Priestorový rozmer sa vztahuje na geografickú polohu. Vo výpovediach respondentov sa domov objavuje ako bezpečný priestor, kde nie je vojna, kde nedochádza k prírodným katastrofám, kde je dostatok pitnej vody. K pozitívnym konotáciám patrí i pekná krajina s rôznorodým prírodným bohatstvom a striedanie štyroch ročných období.

Máme krásne pamiatky a hory, je to velký potenciál. Slovensko je stredom Európy a my máme všetko blízko $[. .].(\mathrm{m}$.$) .$

Bezpečie a príroda prevažovali nad adresným geografickým vymedzením v zmysle vrátit’ sa do konkrétneho mesta/ dediny. Naši respondenti a respondentky sa vrátili najmä tam, kde mali možnost' budovat svoju profesijnú dráhu. A to im ponúkali väčšie a stredne vel'ké mestá na Slovensku a Bratislava. Uplatnenie našli najmä v medzinárodných korporáciách, inštitúciách celoslovenského charakteru, občianskych organizáciách, prípade si vybudovali vlastný biznis. Mestá uprednostňovali aj pre lepšie a rôznorodejšie možnosti aktívne trávit volný čas. Mladí ludia, s ktorými sme realizovali rozhovory lahšie prijímali pracovnú migráciu. Ich „ukotvenie“ ku konkrétnemu geografickému miestu, ku konkrétnemu mestu/ dedine nie je také silné ako v generácii ich rodičov a starých rodičov.

Časová dimenzia sa týka rozdielov, ktoré zmena v čase môže spôsobit. Ide o zlomy v životnom cykle, ako je napríklad uzatvorenie sobáša, narodenie dietata, ponuka práce, smrt' blízkych, rozchod s partnerom, ktoré formujú d’alšie životné osobné a kariérne stratégie. Vzniknuté situácie výrazne ovplyvňujú rozhodnutie vrátit’ sa domov. Na základe výskumov môžeme konštatovat', že vek rozhodnutia sa pre návrat, alebo pre zotrvanie v zahraničí je okolo 30-33 rokov. Uvedené aspekty ilustrujú nasledovné výpovede.

Vel'mi, vel'mi silný faktor je, že ludia po nejakom veku sa chcú usadit a zakladat si rodiny. Alebo ich rodičia prichádzajú do takého veku, že sa o nich treba starat'. Možno že úplne nie hned' v takom zmysle, že potrebujú dennú opateru, ale proste že si uvedomia, že som tu potrebný viac ako kdekolvek inde. Proste prišiel čas, ked’ už chceš íst' domov a tak to aj cítiš, že potrebuješ byt’ doma (̌̌.).

Emocionálna dimenzia zahŕňa vnútorný pocit bezpečia, istôt, lásky, spolupatričnosti, uznávanie rovnakých hodnôt a postojov ku každodenným situáciám i sviatočným príležitostiam. Uvedený rozmer sa viaže na rodinu, rodinné vztahy, kamarátov, ale aj na 
fyzický priestor obsiahnutý v spomienkach na domov. Výrazným faktorom, ktorý vplýval na proces rozhodnutia sa pre návrat bola silná väzba na rodinu, rodinných príslušníkov (naprieč generáciám) a priatel’ov.

Nie je to jednoduché. Aj ked’ tam máte nejakých kamarátov, nie je tam rodina. A to príde časom ako človek dozrieva. Ked’ ste mladý, nepotrebujete nikoho. Stačí vám frajer a kamošky a žúrky. Ale časom si už človek uvedomuje, že tu som doma, tu mám proste rodinu (ž.).

Racionálny rozmer sa týka vážnych, diskurzívnych rozhodnutí migrantov, čo d’alej so svojím životom. Tieto vol'by sú založené na skúsenostiach a životných situáciách migrantov, do ktorých vstupujú nielen ekonomické úvahy, ale aj spomínané emocionálne rozmery. Ide o komplex racionálnych rozhodnutí založit si rodinu, vychovávat̉ dieta $\mathrm{v}$ „domácej krajine“, v generačnom prepojení na starých rodičov a budovat si domov v zmysle fyzického priestoru.

Už sme nechceli žit raz tam, raz tam po podnájmoch. Vedela som, že sa chcem vrátit, že chcem, aby moje diet’a vyrastalo na Slovensku, aby bolo so svojimi starými rodičmi (ž.).

Tento rozmer obsahuje aj sféru plánovania profesijnej dráhy a potrebu rozvijat svoj talent a zručnosti doma. Racionálnou motiváciou pre návrat sú i negatívne skúsenosti z pobytu, nenaplnenie ciel'ov, neuspenie na trhu práce, prítomnost' skleneného stropu i pocity nebezpečenstva a strachu.

A potom, už sme si zarobili celkom dost’ peňazí a mohli sme rozbehnút vlastnú firmu. Ja som chcela vlastné niečo robit. Bola som taká aktívna vel’mi, že mne to nevyhovovalo byt zamestnancom. Takže som chcela vlastnú firmu. A bolo mi jasné, že bude na Slovensku, lebo tu tomu slovenskému svetu rozumiem (ž.).

Pracovala som v takej baliarni na jablká, hrušky. Ako hladala som si aj inakšiu robotu. Bola som aj na pohovore v hoteli, ale oni tam potrebujú ludí ktorí vedia vel’mi dobre po anglicky. No a ja som také skúsenosti nemala. A v tej práci to bolo łažké [...] a nemala som sa kde jazyk naučit. Nemala som tam ani známych, lebo oni majú taký zvláštny štýl života. Bolo to úplne iné ako som chcela (ž.).

\section{Záver}

Fenomén dočasnej migrácie $z$ hladiska jeho procesuálnej povahy obsahuje aj fázu návratu domov. Tú možno rozčlenit na štádium rozhodovania sa pre návrat, samotný odchod z hostitel'skej krajiny i na obdobie prispôsobovania sa staro-novým skutočnostiam v krajine pôvodu. Prostredníctvom analýzy vybraných sledovaných javov sme sa zamerali na to, akú $\mathrm{v}$ tomto procese zohráva kategória domova a aké dimenzie sa s ním 
spájajú. V štúdii sme vychádzali najmä z výskumov mladých ludí, ktorí žili (pracovali, študovali) v zahraničí a vrátili sa domov na Slovensko.

I napriek tomu, že sa na návrat tešili, z analýzy naznačených odpovedí respondentov je evidentné, že rozhodovanie sa preň, ako aj samotný návrat domov, bol zložitý. Dôležitú úlohu zohrávala osobnostná zmena jedinca, snaha o integráciu v hostitel’skej krajine i zmena sociálnych kontaktov a väzieb. V procese návratu dochádzalo k opätovnému vyjednávaniu svojho miesta. Mladí migranti prechádzali vlastnými emóciami, procesom reintegrácie $\mathrm{v}$ sociálnej i v profesionálnej rovine a zároveň boli nútení riešit situácie a požiadavky, ktoré neboli viac či menej schopní ovplyvnit' (napríklad zníženie sociálneho kapitálu). Preto pri konfrontácii nových skúseností a idealizácie domova s realitou došlo $\mathrm{k}$ obrátenému kultúrnemu šoku, čo u niektorých navrátivších viedlo až $\mathrm{k}$ hlbšej individuálnej kríze.

Návratové zámery v procese rozhodovania odrážajú postoje migrantov k migračnej skúsenosti ako celku a zároveň projektujú osobné stratégie a s nimi súvisiaci koncept domova. $V$ štúdii sme ho identifikovali prostredníctvom štyroch prekrývajúcich sa dimenzií (priestorovej, časovej, emocionálnej a racionálnej), ktoré sme podopreli výsledkami terénneho výskumu. Domov sa u mladých reemigrantov spájal so širším významom v kontexte geografického priestoru, vnímania krajiny, prírody i s pocitom bezpečia. Ich návrat sa nespájal s príchodom do rodnej obce/ mesta, ale uprednostňovali stredne velké mestá a Bratislavu, ktoré im poskytli lepšie možnosti profesijného uplatnenia i aktívne trávit vol’ný čas. Výskum ukázal, že významným faktorom pre návrat domov boli rodinné vztahy (rodičia, starí rodičia). Všetci respondenti pozitívne hodnotili podporu zo strany rodičov (emocionálnu i finančnú), spolupatričnost’ a kooperáciu rodiny. Zároveň to bola i potreba formovat životné stratégie - „usadit’ sa “, založit si rodinu, byt' v kontakte s príbuznými (postarat’ sa o rodičov, vychovávat deti v generačnom prepojení), budovat profesijnú dráhu. Ako sme uviedli, ide o prelínajúce sa dimenzie domova, ked'sa nedá oddelit napríklad rozmer časový od emocionálneho a racionálneho. Domov predstavuje aj idealizovaný bod návratu, pocit, túžbu a potrebu vrátit sa. Jedným z dôvodov prečo tomu tak je, prečo prevažovali uvedené faktory rozhodnutí pre návrat, bol vek a vzdelanie respondentov. Osobné rozhovory s respondentmi umožnili preniknút relatívne blízko $\mathrm{k}$ ich pocitom a odkryli i diverzitu migračných skúseností, ked' návrat domov bol i výsledkom neúspechu, nenaplnenia migračného zámeru.

Výskumný materiál poskytuje viaceré témy pre d’alšie vedecké bádanie. Na jednej strane je to napríklad prvok aktívnej komunikácie s okolím súvisiaci s angažovaním sa v zmysle, vraciam sa domov, lebo chcem byt prospešný. Návrat zahŕňa aj ekonomický aspekt spojený s kúpou domu, bytu, zakladanie firiem, start-upov a podobne. $\mathrm{Na}$ strane druhej, návratová migrácia nemusí byṫ trvalá, pretože problematická spätná integrácia môže viest' k opätovnému odchodu. Uvedené problémové okruhy budú predmetom d’alších bádaní. 
The study was created within the framework of the grant project Horizont 2020-YOUNG SOCIETY-693221 Promoting youth involvement and social engagement: opportunities and challenges for 'conflicted' young people across Europe.

\section{Bibliografia}

Bahna M. 2008, Ženy ako migrantky v cudzích domácnostiach. Fenomén au pair a možnosti jeho skúmania, [w:] Piscová M., Bahna M., Zeman M. (eds.), Podoby ženy. Sociologický ústav Slovenskej akadémie vied, Bratislava, s. 43-77.

Bahna M. 2011, Migrácia zo Slovenska po vstupe do Európskej únie, VEDA - Vydavatelstvo Slovenskej akadémie vied, Bratislava.

Bahna M. 2015, Slovenski absolventi vysokoškolského štúdia v zahraniči: Únik mozgov, alebo otvárajúce sa mobilné kanály na Slovensku? "Working Papers in Sociology", No. 1/2015, Sociologický ústav SAV, Bratislava.

Bahna M., Sekulová M. 2019, Crossborder Care: Lessons from Central Europe, Palgrave Macmillan, Cham.

Bitušíková A. 1999, Miesto domova v živote súčasného človeka, "Etnologické rozpravy", Vol. VI, No. 2, s. 7-11.

Bitušíková A. 2006, Transnárodná migrácia z pobliadu sociálnej antropológie, [w:] Luther D. (ed.), E/Migrácie a Slovensko. Diverzita ako faktor transformácí identit. Ústav etnológie SAV, Ústav vedy a výskumu UMB, Bratislava, Banská Bystrica, s. 115-136.

Botíková M. 2014, Súčasné (pracovné cezhraničné) migrácie a ich etnologické štúdium na Slovensku, [w:] Brouček S., Grulich T. (eds.), Nová emigrace z České republiky po roce 1989 a návratová politika (Nábled na problematiku v kontextu vývoje svètových migrací. Etnologický ústav AV ČR, v. v. i., Praha, s. 186-194.

Brickell K.2012,,Mapping'and, doing 'critical geographies of home, "Progress in Humam Grography“, Vol. 36, No. 2, s. 225-244.

Búriková Z. 2006, Prečo majú britské matky au pair a čo sa na tom slovenským au pair nepáči, "Slovenský národopis", Vol. 54, No. 3, s. 341-356.

Búriková Z. 2007, Motivácie au pair migrácie zo Slovenska, "Slovenský národopis“, Vol. 55, No. 4, s. $442-456$.

Búriková Z., Miller, D. 2010, Au pair, Polity, London.

Carling J., Erdal M. B. 2014, Connections between Return Migration and Transnationalism, "Comparative migration studies", Vol. 2, No. 3, s. 361-383.

Cassarino J. P. 2004, Theorising Return Migration: the Conceptual Approach to Return Migrants Revisited, "International Journal on Multicultural Societies (IJMS)", Vol. 6, No. 2, s. 253-279.

Divinský B. 2009, Migračné trendy v Slovenskej republike po vstupe krajiny do EÚ (2004-2008), IOM Medzinárodná organizácia pre migráciu, Bratislava. 
Divinský B., Popjaková D. 2007, Kol'ko Slovákov pracuje v zahranič̨̌? (Jeden expertný odhad), "Forum Statisticum Slovacum”, Vol. 3, No. 3, s. 70-76.

Divinský B., Zachar-Podolinská T. (eds.) 2018, Globe in Motion. Patterns of international migration: Similarities and differences, Ústav etnológie a sociálnej antropológie SAV, Bratislava.

Erdal M. B. 2014, „This is My Home“. Pakistani and Polish Migrants' Return Considerations as Articulations about Home, "Comparative migration studies“, Vol. 2, No. 3, s. 361-383.

Fox L. 2002, The Meaning of Home: A Chimerical Concept or a Legal Challenge? "Journal of Law and Society“, Vol. 29, No 4, s. 580-610.

Galčanová L., Vacková B. 2014, „...když aspoň bydlime v jednom mèstě. “ Město v prožíváni domova samostatně žijicich lidi, "Sociální studia“, Vol. XI, No. 4, s. 13-32.

Gaw K. F. 2000, Reverse culture shock in students returning from overseas, "International Journal of Intercultural Relations“, Vol. 24, No 1, s. 83-104.

Gál F. 1998, O jinakosti, G plus G, Praha.

Grabowska I., Garapich M. P. 2016, Social remittances and intra-EU mobility: non-financial transfers between U.K. and Poland, "Journal of Ethnic and Migration Studies“, Vol. 42, No. 13, s. $2146-2162$.

Gray K. M., Savicky V. 2015, Study Abroad Reentry: Behavior, Affect, and Cultural Distancve, "Frotniers: The Interdisciplinary Journal of Study Abroad", Vol. XXVI, Fall 2015, s. 264-278.

Hlinčíková M., Sekulová, M. 2012, Mladi Európania a Európanky bez hraníc, Iuventa, Slovenský inštitút mládeže, Bratislava.

Jenčová I. 2007a, Vzt’ahy v pohybe - priatel’stvá v Londýne, "Etnologické rozpravy", Vol. XIV, No. 2, s. 9-24.

Jenčová I. 2007b, Migrácia ako dobrodružstvo, "Slovenský národopis“, Vol. 55, No. 4, s. 457-463.

Jenčová I. 2008, Inštitúcie a vytváranie spoločnej komunity Slovákov a Čechov v Londýne, "Etnologické rozpravy“, Vol. XV, No. 1, s. 25-35.

Luther D. (ed.) 2006a, E/Migrácie a Slovensko. Diverzita ako faktor transformácií identit, Ústav etnológie SAV, Ústav vedy a výskumu UMB, Bratislava, Banská Bystrica.

Luther D. 2006b, Koncepty domova a vzt'ahy slovenských migrantov a emigrantov $k$ domovine (postoje sprostredkované internetom), [w:] Luther D. (ed.), E/Migrácie a Slovensko. Diverzita ako faktor transformácií identit. Ústav etnológie SAV, Ústav vedy a výskumu UMB, Bratislava, Banská Bystrica, s. 95-114.

Majerová D. 2016, Migračné a integračné procesy v globálnom vel'komeste (na príklade slovenských migrantiek v Londýne), Katedra sociálnych štúdií a etnológie FF Univerzita Mateja Bela v Banskej Bystrici, Banská Bystrica.

Mallett S. 2004, Understanding Home: A Critical Review of the Literature, "The Sociological Review“, Vol. 52, No.1, s. 62-89.

Martin R., Radu D. 2012, Return Migration: The Experience of Eastern Europe, "International Migration“, Vol. 50, No. 6, s. 109-128. 
Paríková M. 2001, Reemigrácia Slovákov z Mad’arska v rokoch 1946-48. Etnokultúrne a sociálne procesy, STIMUL - Centrum informatiky a vzdelávania FiF UK, Bratislava.

Sekulová M. 2015, „Najčistotnejšie, najzodpovednejšie, najpracovitejšie“. Slovenské opatrovatel’ky senioriek a seniorov v Rakúsku, [w:] Kobová L'. (ed.), Feministky hovoria o práci. Ako sa ženy stávajú subjektmi kapitalizmu. Aspekt, Bratislava, s. 101-134.

Szaló C. 2006, Domov a jiná místa/ne-mistaformování kulturních identit, "Sociální studia“, Vol. 3, No. 1 , s. $145-160$.

Szaló C. 2007, Transnacionálni migrace. Promèny identit, hranic a védění o nich. Centrum pro studium demokracie a kultury, Sociologická řada, sv. 5, Brno.

Vertovec S. 1999, Conceiving and researching transnationalism, "Ethnic and Racial Studies", Vol. 22, No. 2, s. 447-462.

Westwood M. J., Lawrence W. S., Paul, D. 1986, Preparing for re-entry; a program for the sojourning student, "International Journal for the Advancement of Counselling“, Vol. 9, No. 3, s. 221-230.

\section{Internetové zdroje}

Official website of Medzinárodná organizácia pre migráciu (IOM), https://www.iom.sk/sk/pre -media/zakladne-pojmy-o-migracii.html\#migracia, 8. 11. 2018. 
